\title{
The (De-)Anchoring of Inflation Expectations: New Evidence from the Euro Area
}

\author{
Laura Pagenhardt* \\ Dieter Nautz* \\ Till Strohsal*
}

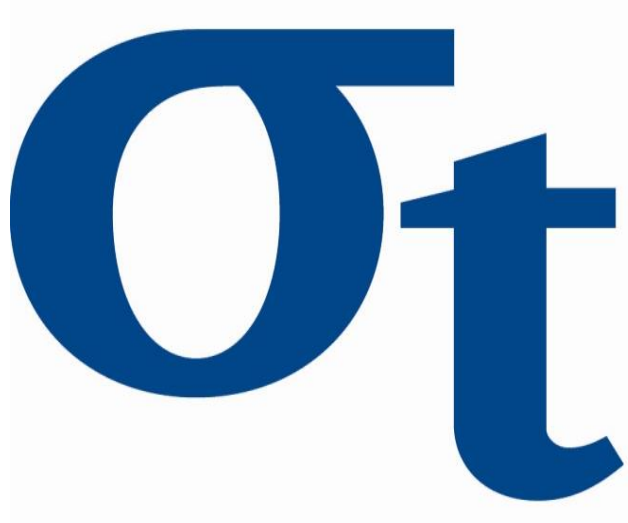




\title{
The (De-)Anchoring of Inflation Expectations: New Evidence from the Euro Area
}

\author{
Laura Pagenhardt, Dieter Nautz and Till Strohsal* \\ Freie Universität Berlin \\ Department of Economics
}

This version:

September 1, 2015

\begin{abstract}
Well-anchored inflation expectations are a key factor for achieving economic stability. This paper provides new empirical results on the anchoring of long-term inflation expectations in the euro area. In line with earlier evidence, we find that euro area inflation expectations have been anchored until fall 2011. Since then, however, they respond significantly to macroeconomic news. Our results obtained from multiple endogenous break point tests suggest that euro area inflation expectations have remained de-anchored ever since.

Keywords: Anchoring of Inflation Expectations, Break-Even Inflation Rates, News-Regressions, Multiple Structural Break Tests
\end{abstract}

JEL classification: E31, E52, E58, C22

\footnotetext{
*Financial support from the Deutsche Forschungsgemeinschaft (DFG) through CRC 649 Economic Risk is gratefully acknowledged.

E-mail: lpagenhardt@fu-berlin.de; dieter.nautz@fu-berlin.de; till.strohsal@fu-berlin.de, phone: +49 (0)30 838-53399.
} 


\section{Introduction}

There is a growing consensus among both, central bankers and academics that wellanchored inflation expectations are a key factor for achieving economic stability. Consequently, inflation expectations are increasingly used as an indicator for the credibility of monetary policy and the central bank's inflation target. In the empirical literature, the predominant criterion to test the anchoring of inflation expectations is based on the idea that firmly anchored expectations should be insensitive to the announcement of macroeconomic news, see e.g. Gürkaynak et al. (2010b). If long-term inflation expectations remain unaffected by incoming economic surprises, economic agents apparently trust the ability of the central bank to maintain its inflation target in spite of the unexpected economic developments. By contrast, if the credibility of the central bank is only weak and inflation expectations are de-anchored, surprises in macroeconomic announcements can lead to unwanted changes in expectations, away from the given inflation target.

Many central banks have adopted an inflation-targeting system as a tool for anchoring long-term inflation expectations ${ }_{1}^{1}$ A leading example is the European Central Bank (ECB) which is very clear about her inflation target of "below, but close to $2 \%$ " ? In the aftermath of the financial crisis and, particularly, during the following European sovereign debt crisis, there has been a heated debate about the credibility of the ECB's inflation target. Galati et al. (2011) and Autrup and Grothe (2014) show that inflation expectations in the euro area are well-anchored. However, these results are based on data ending March 2009 and July 2012, respectively. To the best of our knowledge, more recent evidence on the anchoring of long-term inflation expectations in the euro area is not available. The current paper tries to fill this gap by providing new empirical evidence on the impact of the recent European sovereign debt crisis on inflation expectations anchoring in the euro area.

\footnotetext{
${ }^{1}$ During the financial crisis, inflation targeting has often been blamed for preventing monetary authorities from appropriately responding to financial systemic risk. Recent evidence shows, however, that inflation targeting countries have, on average, a more stable financial system, see Fazio et al. (2015).

${ }^{2}$ Inflation targets are used by an increasing number of central banks all over the world. The information about the target is, however, provided in very different ways. For example, there are several central banks, including the Reserve Bank of New Zealand, the Bank of England, or the Bank of Sweden, that have published their intended level of the inflation rate for many years. By contrast, the U.S. Federal Reserve (Fed) had only an implicit inflation targeting regime without an explicit, numerically expressed inflation target up till the end of January 2012.
} 
In the course of the ongoing European sovereign debt crisis, the challenges for monetary policy have increased tremendously. After Mario Draghi's announcement in July 2012 that the ECB would do "whatever it takes" to save the Euro (Draghi, 2012), government bond yields stopped rising but economic risks remained high in several euro area countries. As a consequence, more unconventional monetary policy measures followed. In order to stabilize markets and engage investment activity, the ECB changed its communication strategy by implementing forward guidance in July 2013, thereby breaking with a long-kept tradition to never pre-commit to a future interest rate path $(\mathrm{ECB}, 2014)$. Interest rates were lowered continually, reaching negative deposit facility rates and a fixed refinancing rate as low as 0.05\% in October 2014. Finally, the ECB announced the implementation of a quantitativeeasing (asset purchase) program, feeding a monthly amount of $€ 60$ billion into European markets until March 2016, see ECB (2012b).

Interestingly, the direction of the effect of the crisis-related uncertainty on inflation expectations is not obvious. On the one hand, the vast amount of additional liquidity provided by the ECB may lead to expectations that inflation will rise above $2 \%$ eventually. On the other hand, the possibility that currently very low or even negative inflation rates induce a deflationary spiral could trigger strong downward corrections of inflation expectations. In either case, inflation expectations in the euro area would be less anchored, reacting more sensitively to macroeconomic news.

The aim of this paper is twofold. First, we examine whether there has been a recent deanchoring of inflation expectations in the euro area. And second, if that is the case, we test whether inflation expectations have been successfully re-anchored ever since. Following Nautz and Strohsal (2015), we address these questions by applying the multiple endogenous break point tests of Bai (1997) and Bai and Perron (1998). In accordance with Galati et al. (2011) and Autrup and Grothe (2014), our empirical results show that the sensitivity of euro area inflation expectations to macroeconomic news is only weak until September 2011. However, the break point tests and the corresponding news regression clearly demonstrate that euro area inflation expectations have been de-anchored ever since. These results indicate that the credibility of the ECB's inflation target has suffered significantly from the 
protracted European sovereign debt crisis and that it has not been re-established so far.

The rest of the paper is structured as follows. Section 2 briefly reviews the literature on inflation expectations anchoring. Section 3 discusses the measurement of inflation expectations and introduces the data employed for macroeconomic news. Section 4 presents the empirical results based on news-regressions and endogenous break tests. Finally, Section 5 concludes.

\section{Anchoring of Inflation Expectations in the Euro Area:}

\section{A Brief Review of the Literature}

A natural starting point for a review of the literature on inflation expectations anchoring is Friedmann (1961). He already emphasized that there are lags in the consequences of monetary policy actions implying that they should be based on expectations about future inflation and not on current inflation. Until recently, a characteristic feature of traditional economic theory has been the assumption of rational expectations that are based on a fixed and known structure of the economy. In these models, surprises about macroeconomic variables can only lead to transitory deviations of the inflation rate from its target level implying that macroeconomic news do not affect long-run inflation expectations.

The impact of macroeconomic news on inflation expectations increases, however, if economic agents are uncertain about the model's structure, its time invariance or some of its parameters. Orphanides and Williams (2005) propose a model where agents have only imperfect knowledge of the economy's structure including the central bank's inflation target. Yet they learn perpetually and update their expectations about the structure of the model by evaluating the observed economic shocks and their expectational errors. In this framework, higher uncertainty about the central bank's inflation target implies that inflation expectations become more sensitive to macroeconomic news. Orphanides and Williams (2005) show that the sensitivity to macroeconomic news can be reduced by successful central bank communication.

Demertzis and Viegi (2008, 2009) argue that an explicit inflation target provides a focal 
point for agents to form expectations when their information is imperfect. In their initial model, expectations are formed on the basis of three aspects: Firstly, monetary authorities' objectives and their decisions, secondly, shocks that take place after decisions are taken, and thirdly, the average of the individuals' expectations. Introducing a publicly communicated target by the central bank to the model, they show that individuals will form their expectations around that target instead of basing them on the other three aspects, given the target is sufficiently credible. Today, it is widely accepted by both, central banks and academics that a credible inflation target can serve as an anchor for long-run inflation expectations, see e.g. Bank of Canada (2015).

In case of uncertainty about the central bank's inflation target, economic agents update their expectations about future inflation in response to the new information contained in announcements of macroeconomic key variables and monetary policy measures. By contrast, if the central bank's target is credible and long-term inflation expectations are wellanchored, they should not be sensitive to macroeconomic news. Therefore, Gürkaynak et al. (2005) proposed to test the anchoring of inflation expectations by their sensitivity to surprises in macroeconomic announcements. To this end, surveys of professional or consumer forecasts are exploited to obtain the news component of a macroeconomic announcement, typically defined as the difference between the expected and the realized value of a variable.

In the empirical literature, evaluating the response of inflation expectations to macroeconomic news has become the standard approach to test for inflation expectation anchoring. Using U.S. data from 1990 to 2002, Gürkaynak et al. (2005) showed that macroeconomic news have a significant impact on medium as well as long-term inflation rates. Accordingly, they conclude that U.S. inflation expectations were not entirely anchored over that period. More recent empirical contributions suggest that, compared with inflation targeting central banks like the ECB, inflation expectations were less anchored in the case of the Fed. Gürkaynak et al. (2010b) compare the anchoring of inflation expectations in the U.S. and the United Kingdom (U.K.) before and after 1997, which is when the Bank of England became independent. In line with prior research, they find that, before 1997, inflation expectations in the U.S. and in the U.K. were similarly volatile and responsive to macroeconomic news. 
After 1997, however, the responsiveness of U.K. expectations to news strongly decreased. Gürkaynak et al. (2010b) conclude that a transparent and credible inflation-targeting policy supports the anchoring of market participants' perceptions of long-term inflation development.

In line with Gürkaynak et al. (2010b), the inflation targeting policy and the elaborated communication strategy of the ECB may have contributed to a firm anchoring of inflation expectations in the euro area, particularly before the outbreak of the financial crisis. In an analysis of pre-crisis data, Beechey et al. (2011) find that inflation expectations react systematically to various types of surprises in the U.S., but not in the euro area. Similar results were obtained by Galati et al. (2011), who include the U.K. as well as some data (until March 2009) from the crisis years. Galati et al. (2011) introduced structural break point tests in order to allow for a changing degree of inflation expectations anchoring. While there are crisis-related breaks in the news regressions for all three currencies under consideration, their results confirm that euro area inflation expectations remained well-anchored in the aftermath of the Lehman breakdown. In contrast, U.S. inflation expectations reacted significantly more strongly to macroeconomic news after the outbreak of the financial crisis. Nautz and Strohsal (2015) provide further support for a crisis-related de-anchoring of U.S. inflation expectations. Strohsal and Winkelmann (2015) employ an exponential smooth transition autoregressive (ESTAR) model to inflation expectations for the U.S., U.K., Sweden and the euro area using data until February 2011. They also confirm that the strongest degree of anchoring can be found in the euro area, followed by the U.S., Sweden and the U.K.

The most recent evidence on the anchoring of inflation expectations in the euro area is provided by Autrup and Grothe (2014). Using data until July 2012, they allow for an exogenous break in the degree of anchoring by splitting the observations into a pre-crisis and a crisis sample. They confirm that long-term inflation expectations in the U.S. became more sensitive to macroeconomic news in the crisis period. By contrast, euro area long-term inflation expectations are anchored for both the pre-crisis and the crisis period. 
Overall, there is a clear consensus in the empirical literature that euro area inflation expectations have been well-anchored - at least until 2011. The question remains, however, whether this anchoring has also survived the turbulences stirred by the ongoing European sovereign debt crisis. In the following empirical analysis, we investigate this issue by applying multiple endogenous break point tests to euro area inflation expectations data reaching as far as January 2015.

\section{Inflation Expectations and Macroeconomic News: The Data}

\subsection{Measuring Inflation Expectations}

The empirical literature takes data about inflation expectations either from surveys or from break-even inflation rates derived from inflation-indexed government bonds. In the following, we weigh the pros and cons of both kinds of measures in order to explain why market-based measures of inflation expectations are the more appropriate measure in our application.

Survey-Based Measures of Inflation Expectations Surveys involving both consumers and professional forecasters are conducted by various European institutions on a regular basis. For example, in the European Commission Consumer Survey on Inflation Expectations, consumers are asked monthly to indicate their expectations in terms of the direction of inflation development over the next year. The ECB Survey of Professional Forecasters (SPF) is conducted quarterly and includes a panel of more than 70 forecast experts ${ }^{3}$ There is no doubt that survey measures contain valuable information and should serve as an important benchmark for the assessment of inflation expectations. For example, recent studies employ surveys to learn more about the rationale behind individual forecasts (Schmidt and Nautz, 2012) as well as the determinants (Dovern et al. 2012) and the information content (Legerstee and Franses, 2015) of forecaster disagreement. Yet, as Galati et al. (2011) already

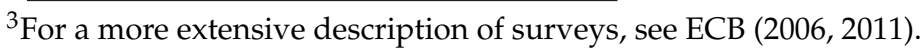


emphasized, all this information is only available on a low-frequency which makes it difficult to analyze breaks and a time-varying degree of expectations anchoring. Particularly in a crisis period, a central bank monitoring vigilantly the credibility of its inflation target cannot wait for a whole quarter until the next survey is available.

In addition to the low-frequency problem of surveys, there are further psychological and sociological factors that may influence and distort the information content of surveys: As first shown by Loftus and Palmer (1974) in an experimental environment, the response to questionnaires is highly sensitive to the phrasing of the questions. In an application to inflation-expectation surveys, van der Klaauw et al. (2008) found that different types of questions may lead to different interpretations and a lower level of agreement amongst participants. An additional distorting effect could be due to socially desirable responding, defined as the tendency to answer in a manner that will be viewed favorable by others, in particular by the issuer of the questionnaire, see Paulhus (2002). In our application, this effect may lead forecasters responding in line with the ECB's target. Following Smith (1982), this shows that survey measures might be unreliable because respondents are not obliged to act according to their provided information. In view of these problems of survey data, the empirical literature predominantly employs break-even inflation rates as a measure of inflation expectations derived from marketable instruments.

Break-Even Inflation Rates According to the Fisher equation, the yield of a nominal bond equals the real yield plus expected inflation. Break-even inflation (BEI) rates, often called inflation compensation, are defined as the spread between yields of nominal and inflationindexed government bonds with the same maturity. An index-linked bond has a principal value and payments which are connected to a price index, in the case of Europe the Harmonized Index of Consumer Prices (HICP). The BEI rate therefore reflects the rate at which the expected real return on both bonds would be equal, given the bonds were held until maturity. As a market based measure of inflation expectations, BEI rates avoid many problems of measures taken from inflation surveys. First of all, data frequency is not an issue since BEI rates are easily available on a daily basis. In contrast to survey-based measures, BEI 
rates are determined by market activities and actual trading behavior. Therefore, BEI rates can be considered to represent the market's actual inflation expectations and should not be distorted by psychological factors, see ECB (2006). Of course, using BEI rates as a measure of inflation expectations is also not without problems. In the following, we show how the empirical literature using BEI rates accounts for the effects of liquidity and risk premia.

\subsection{Adjusting BEI Rates for Risk}

Inflation-Risk Premium The inflation-risk premium compensates investors for uncertainty about future inflation rates and pushes BEI rates up (Gürkaynak et al., 2010a). Following Strohsal and Winkelmann (2015), this component should be considered a relevant aspect of inflation expectations. If the inflation-risk premium is high, this suggests an elevated level of uncertainty about future inflation and thus about long-term monetary stability. In line with Beechey et al. (2011), we do not eliminate the inflation-risk premium since central banks should aim to minimize this uncertainty in order to anchor inflation expectations. Moreover, Hördahl (2008, pp. 23-38) argues that inflation-risk premia are often found to be small and fairly stable, implying that their impact on daily changes in BEI rates should be negligible.

Liquidity Premium A liquidity premium is demanded by investors if a security cannot easily be converted into cash. Since inflation-indexed bonds are usually traded less frequently than nominal bonds, liquidity premia could be important for the development of BEI rates. The liquidity premium component lowers the extracted inflation expectations. Liquidity effects should be particularly pronounced in a crisis period when financial markets experience great fluctuations in volatility and liquidity, see Galati et al. (2011). Consequently, in an analysis of recent euro area BEI rates, liquidity effects cannot be ignored.

Following Gürkaynak et al. (2010a), the empirical literature accounts for liquidity effects by using a pre-regression of BEI rates on liquidity control variables. In line with e.g. Strohsal and Winkelmann (2015), we regress the BEI rate, BEIR, on a corporate bond spread and a 
volatility proxy:

$$
B E I R_{t}=\gamma+\delta_{1} \text { spread }_{t}+\delta_{2} \operatorname{VIX}_{t}+f_{t}
$$

The control variable spread $_{t}$ is the difference between an AAA-rated corporate bond yield and the yield of a nominal government bond. For both types of securities, the credit risk component is considered to be near zero, so that differences in the bond yields should be based on differences in liquidity in both markets. According to Christensen and Gillan (2012), the corporate spread represents a reasonable instrument in (1) because liquidity pre-

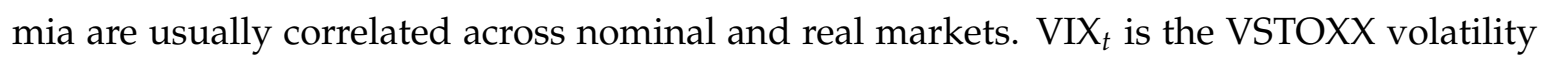
index, which serves as a proxy for market volatility. More detailed information about the data and the results of the adjustment equation (1) is provided in the Appendix. The residual term of equation (1), $f_{t}$, represents the liquidity-adjusted BEI rate for this particular sample and is used in the subsequent analysis as the measure of long-term inflation expectations.

\subsection{Spot Versus Forward Break-Even Rates}

The literature distinguishes between spot and forward break-even rates of inflation. Spot rates refer to securities that are purchased and exchanged right away (on the spot). The 10-year break-even spot rate, for example, is a measure of the average expected inflation rate over the next 10 years. This implies that the 10 -year spot rate also reflects short-term expectations of inflation rates over the next year, the year thereafter and so on, since these values enter the average. As a result, spot rates are found to be strongly affected by short-term shocks and are more volatile than forward rates, see ECB (2012a). Inflation targets and, thus, the relevant expectations horizon refer to the medium and long run. As a consequence, forward rates are a more suitable measure of long-run inflation expectations. Forwards are contracted today but refer to a rate in the future. For instance, the 5-year forward rate 5 years ahead represents the yield of a 5-year bond starting in 5 years (and ending in 10 years) agreed on today. Far-ahead forward rates hence eliminate the influence of short-term fluctuations and should be closely linked to the inflation target.

In our empirical analysis, we use 5-year forward BEI rates 5 years ahead for investigating 
expectations anchoring in the euro area. This particular forward maturity is predominantly used both in practice (ECB, 2012a) and in the empirical literature. The data are taken from the European Central Bank and Bloomberg, see Appendix A

5-year forward BEI rates 5 years ahead $(B E I R)$ are derived as follows:

$$
B E I R_{t}=\left(\frac{\left(1+r_{10}\right)^{10}}{\left(1+r_{5}\right)^{5}}\right)^{\frac{1}{10-5}}-1
$$

where $r_{i}$ represents the BEI spot rate with maturity of $i$ years.

Taking logs provides a more intuitive interpretation of the forward rate as the average expected inflation rate over the period that starts in 5 years and then lasts for 5 years:

$$
B E I R_{t} \approx \frac{1}{5}\left(10 r_{10}-5 r_{5}\right)
$$

The break-even inflation rate $(B E I R)$ is shown in Figure 1. Note that the break-even rate is

Figure 1 Long-Run Forward Break-Even Inflation Rate in the Euro Area

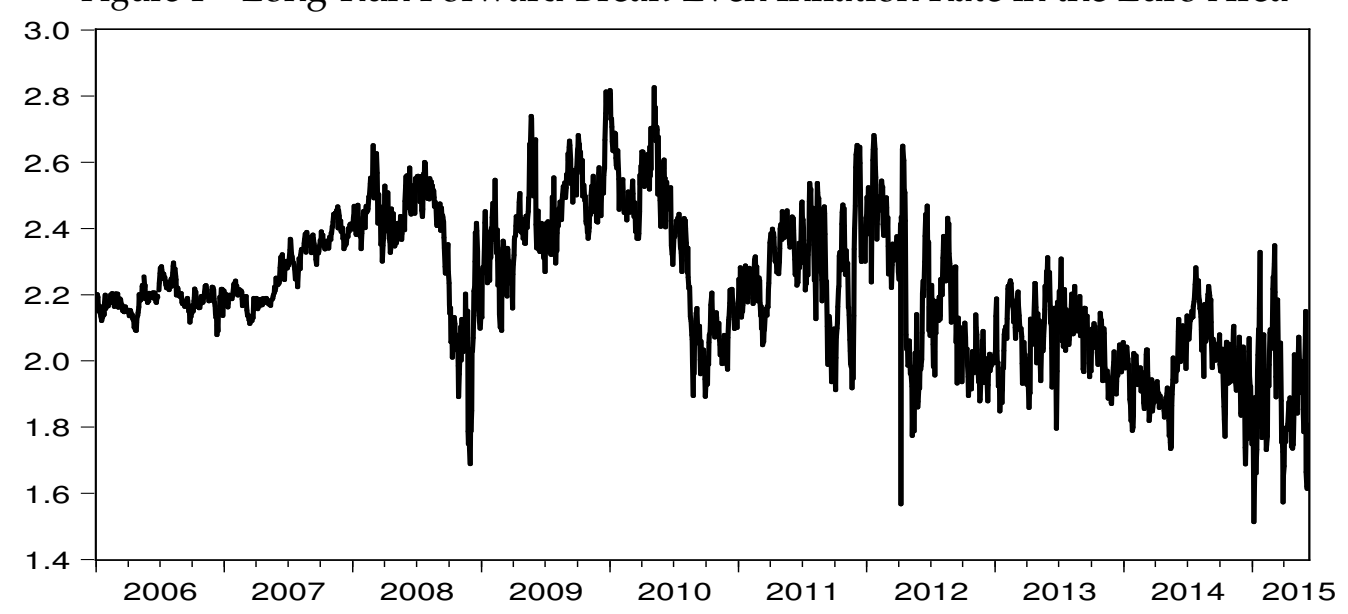

Notes: The figure shows the 5-year forward break-even inflation rate 5 years ahead with respect to the Harmonized Consumer Price Index.

above but close to the ECB's target of $2 \%$. Inflation expectations went up during the height of the financial crisis, until 2009, and have been going down persistently thereafter, reaching their lowest value on 6th January 2015. Figure 1 also suggests that the volatility of inflation 
expectations has increased recently. According to Galati et al. (2011), more volatile inflation expectations can be an indicator of a lower degree of anchoring.

\subsection{Macroeconomic News Variables}

In line with the literature, we estimate the impact of macroeconomic news to determine the degree of anchoring of inflation expectations. Realizations of economic variables are released on a monthly or quarterly basis. Around one week before each data release, professionals provide their forecasts about the surveyed variables. Since the predicted component of the news variable should be priced in at the data release date, it should have no effect on inflation expectations in any case (Gürkaynak et al., 2010b). By contrast, the news component of a macroeconomic announcement, calculated as the difference between the actual release value and the median forecast, may affect de-anchored inflation expectations. Surprises are realized on the date the value of the underlying variable is published by the officials. On non-publication dates, surprises are set to zero.

Our set of macroeconomic news variables include measures on economic activity (GDP, industrial production, unemployment rate, trade balance with non-EU), prices (CPI, PPI) and government expenditure in the euro area. In line with the empirical literature, the proxy for the monetary policy surprise is based on the three-month Euro Interbank Offered Rate (Euribor). The Euribor should not respond to the anticipated component of central bank announcements. The ECB publishes its monetary policy decisions once a month, usually at the first Thursday, at 1.45pm central European time (CET). Since the Euribor is published daily at 11.00am CET, the change of the Euribor on the day after a monetary policy announcement should capture reactions to monetary surprises. More information about the news data is given in the Appendix. 


\section{The Anchoring of Inflation Expectations in the Euro Area: Empirical Results}

\subsection{Do Inflation Expectations Respond to Macroeconomic News?}

In order to investigate the anchoring of euro area inflation expectations we regress the change of liquidity-adjusted BEI forward rates on a set of macroeconomic news variables, collected in the vector $\mathbf{X}_{t}$ :

$$
\Delta f_{t}=\alpha+\beta \mathbf{X}_{t}+\epsilon_{t}
$$

where $t$ indexes days and the dependent variable $\Delta f_{t}=f_{t}-f_{t-1}$ represents the daily change in the liquidity-adjusted 5-year forward BEI rate 5 years ahead. If inflation expectations are well-anchored, $\Delta f_{t}$ will not react to $\mathbf{X}_{t}$ implying that $\beta$ will be small and insignificant. In contrast, significant $\beta$-coefficients would indicate responsiveness of inflation expectations to macroeconomic news, suggesting a lack of anchoring.

In a first step of our analysis, we assume a constant degree of anchoring and, thus, conduct the news-regression for the entire sample period, January 2006 to January 2015. The results are presented in Table 1. According to these preliminary results, inflation expecta-

Table 1 The Anchoring of Inflation Expectations in the Euro Area: Results from News Regressions without a Break

\begin{tabular}{|c|cccccccc|c|c|}
\hline sample & GDP & IP & UER & TB & CPI & PPI & GEP & Euribor & joint test & $R^{2}$ \\
\hline $01 / 03 / 2006-$ & 0.010 & -0.005 & -0.068 & -0.005 & -0.009 & -0.027 & 0.029 & $\mathbf{0 . 3 9 5}$ & 1.456 & 0.005 \\
$01 / 30 / 2015$ & $(0.72)$ & $(0.43)$ & $(0.23)$ & $(0.11)$ & $(0.26)$ & $(0.26)$ & $(0.30)$ & $(0.06)$ & $(0.17)$ & \\
\hline
\end{tabular}

Notes: Least-squares estimation of $\Delta f_{t}=\alpha+\beta \mathbf{X}_{t}+\epsilon_{t}$ with $p$-values based on Newey-West standard errors given in parentheses. The news variables are: GDP, industrial production (IP), unemployment rate (UER), trade balance $(\mathrm{TB})$, consumer price index $(\mathrm{CPI})$, producer price index (PPI) and government expenditure (GEP). Euribor changes measure monetary policy surprises. The joint test statistic, with $p$-value in parentheses, refers to the null hypothesis that all news-coefficients are equal to zero.

tions have been reasonably well-anchored in the euro area over the whole sample period. Each individual macroeconomic news variable as well as the test statistic for a joint effect of all news variables are insignificant and the $R^{2}$ is as small as $0.5 \%$. The major exception refers 
to the Euribor surprise ( $p$-value of 0.06 ), indicating some sensitivity of long-term inflation expectations to monetary policy announcements.

\subsection{Is the Degree of Inflation Expectations Anchoring Constant over Time?}

Credibility can be gained but it can also be lost. In particular, the degree of anchoring of inflation expectations might not be constant over time. In order to investigate whether the anchoring of European inflation expectations has survived the sovereign debt-crisis, regression (4) should be allowed to exhibit structural breaks implying time-varying parameters. In order to investigate the parameter stability issue, we apply endogenous break point tests.

In order to allow for multiple breaks in the way euro area inflation expectations respond to news, we use the Bai (1997) sequential test as well as the Bai and Perron (1998) test which combines the sequential with a global approach. A convenient feature of these tests is that they are based on a Wald-statistic which allows to use robust variance-covariance estimators. In the empirical analysis, our inference is based on Newey-West autocorrelation and heteroskedasticity consistent (HAC) standard errors. Since the data used in this analysis cover the years from 2006 to 2015, they include four possible regimes: pre-crisis, financial crisis, sovereign debt crisis and a potential recovery phase. Therefore, we allow for a maximum of three structural breaks. Further details on the multiple break point test methodology are provided in Appendix $\mathrm{C}$.

The results of the endogenous break point tests are shown in Table 2 . For both tests, there is a minimum number of observations per regime. The results shown are based on the standard trimming percentage of $15 \%$, i.e. $7.5 \%$ of the data are cut off at each end of the sample. It is worth emphasizing, however, that our results do not depend on that choice. Note that the consistency of the test results is high, both regarding the number of significant breaks and their timing. In line with earlier evidence on the anchoring of Euro inflation expectations, both test variants do not find a significant break at the outbreak of the financial crisis in 2008. However, the break point tests do agree on a significant break point at the beginning of September 2011 when the European sovereign debt crisis has already unfolded. 
Moreover, neither the sequential Bai (1997) nor the combined Bai and Perron (1998) test indicates the existence of a second (or third) break. This suggests that the new anchoring regime of euro area inflation expectations that has started in late 2011 still continues.

Table 2 Tests of Time-Invariant Degree of Inflation Expectations Anchoring

\begin{tabular}{|c|c|c|c|c|c|c|c|}
\hline test variant & breaks & break date & $\begin{array}{l}\text { test } \\
\text { stat. }\end{array}$ & $\begin{array}{l}5 \% \text { crit. } \\
\text { value }\end{array}$ & breaks & $\begin{array}{l}\text { test } \\
\text { stat. }\end{array}$ & $\begin{array}{c}10 \% \text { crit. } \\
\text { value }\end{array}$ \\
\hline \multirow[t]{2}{*}{ Bai (1997) } & \multirow[t]{2}{*}{1} & \multirow[t]{2}{*}{ 09/01/2011 } & \multirow[t]{2}{*}{24.22} & \multirow[t]{2}{*}{23.70} & \multirow[t]{2}{*}{2} & $15.85^{\dagger}$ & 23.62 \\
\hline & & & & & & $5.57^{+\dagger}$ & 23.62 \\
\hline \multirow[t]{2}{*}{ Bai and Perron (1998) } & \multirow[t]{2}{*}{1} & \multirow[t]{2}{*}{ 09/06/2011 } & \multirow[t]{2}{*}{24.22} & \multirow[t]{2}{*}{23.70} & 2 & 15.85 & 23.62 \\
\hline & & & & & 3 & 11.53 & 24.74 \\
\hline
\end{tabular}

Notes: The sequential Bai (1997) test searches in the subsamples before and after 09/01/2011 for a second break. †Most significant test statistic for a break before 09/01/2011. ††Most significant test statistic for a break after 09/01/2011. In the combined test of Bai and Perron (1998), the timing for all breaks under the alternative hypothesis is determined by a global search and subsequently the most likely additional break date is tested for significance. A $15 \%$ trimming has applied to all test variants. Critical values are taken from Bai and Perron (2003b).

\subsection{How Did the Break in the News-Regression Affect the Anchoring of Inflation Expectations?}

Table 3 shows the results from the news regression over the two sub-periods indicated by the break tests. The estimation confirms that break-even rates did not react significantly to news in the first sub-sample, i.e. before the break point at 09/01/2011. The the test of joint significance of all regressors does not reject the irrelevance of macroeconomic news for inflation expectations and the coefficient of determination is only $0.4 \%$. This result is perfectly in line with earlier findings of e.g. Autrup and Grothe (2014) and Strohsal and Winkelmann (2015). In particular, it is confirmed that inflation expectations in the euro area remained well-anchored during the financial crisis in 2008.

From September 2011 onwards, however, we obtain a different picture. Table 3 shows a clear de-anchoring of inflation expectations in the second period, i.e. from 09/01/2011 to $01 / 30 / 2015$. This de-anchoring is reflected in significant responses to several macroeco- 
nomic news. The joint test is significant at any conventional confidence level and the $R^{2}$ increased from $0.4 \%$ to $2.6 \%$. This suggests that the ongoing sovereign debt crisis led to a destabilization of inflation expectations.

Table 3 The (De-)Anchoring of Inflation Expectations in the Euro Area: Results from News Regressions with a Single Break

\begin{tabular}{|c|cccccccc|c|c|}
\hline period & GDP & IP & UER & TB & CPI & PPI & GEP & Euribor & joint test & $R^{2}$ \\
\hline $01 / 03 / 2006-$ & 0.005 & -0.003 & -0.018 & $\mathbf{- 0 . 0 0 6}$ & 0.039 & 0.016 & 0.000 & 0.052 & 0.827 & 0.004 \\
$08 / 31 / 2011$ & $(0.86)$ & $(0.68)$ & $(0.78)$ & $(0.04)$ & $(0.61)$ & $(0.22)$ & $(0.99)$ & $(0.70)$ & $(0.58)$ & \\
\hline $09 / 01 / 2011-$ & 0.013 & -0.007 & $\mathbf{- 0 . 1 7 1}$ & -0.003 & $\mathbf{- 0 . 3 9 1}$ & $\mathbf{- 0 . 1 3 7}$ & $\mathbf{0 . 2 2 9}$ & $\mathbf{1 . 2 7 6}$ & $\mathbf{3 . 8 1 4}$ & 0.026 \\
$01 / 30 / 2015$ & $(0.88)$ & $(0.50)$ & $(0.09)$ & $(0.67)$ & $(0.03)$ & $(0.05)$ & $(0.02)$ & $(0.00)$ & $(0.00)$ & \\
\hline
\end{tabular}

Notes: The time-varying impact of macroeconomic news on inflation expectations. The joint test statistic, with $p$-value in parentheses, refers to the null hypothesis that all newscoefficients are equal to zero. For more information, see Table 1 (notation and statistics), Table 2 (break point analysis), and Table 4 in Appendix A (data).

The absence of significant second break indicates that euro area inflation expectations have not been re-anchored ever since. It is worth noting that the most likely second break (which is, however, insignificant even at the 10\% confidence level) is found before, not after 2011, compare Table 2. The break test statistic (5.57) corresponding to the most likely break in the post-2011 period is even less significant.

\section{Conclusion}

Before the financial crisis, the performance of the ECB was viewed with general satisfaction. In line with the ECB's commitment to price stability as the primary goal of monetary policy, its achievements in curbing inflation and anchoring expectations contributed to the credibility of monetary policy in the euro area. Based on data up till July 2012, several empirical contributions, including Beechey et al. (2011), Galati et al. (2011) and Autrup and Grothe (2014) confirmed that inflation expectations are well-anchored in the euro area since they do not respond sensitively to economic news.

In the course of the ongoing sovereign debt crisis, however, concerns were raised that 
euro area inflation expectations became de-anchored. On the one hand, due to substantial quantitative easing and prolonged low interest rate levels, the ECB could face problems of inflation in the longer-run. On the other hand, current inflation rates close to zero could also lead to severe downward corrections of long-term inflation expectations.

This paper provides new evidence on the anchoring of inflation expectations in the euro area. In accordance with earlier studies, we find that euro area inflation expectations were well-anchored until fall 2011. Since then, however, it is revealed that long-term inflation expectations are less anchored and respond significantly to macroeconomic news. The results obtained from multiple endogenous break tests suggest that euro area inflation expectations have remained de-anchored ever since. Our empirical results indicate that the continuation of the sovereign debt crisis has not only raised serious concerns about the integrity of the euro area, but it may also have increased the uncertainty about the monetary policy strategy of the ECB and, particularly, the relevance of the inflation target.

\section{References}

Autrup, S. L. and Grothe, M. (2014). Economic surprises and inflation expectations: Has anchoring of expectations survived the crisis? European Central Bank Working Paper Series, 1671.

Bai, J. (1997). Estimating multiple breaks one at a time. Econometric Theory, 13(3):pp. 315-352.

Bai, J. and Perron, P. (1998). Estimating and testing linear models with multiple structural changes. Econometrica, 66(1):pp. 47-78.

Bai, J. and Perron, P. (2003a). Computation and analysis of multipe structural change models. Journal of Applied Econometrics, 18:1-22.

Bai, J. and Perron, P. (2003b). Critical values for multiple structural change tests. Econometric Journal, 6:22-78.

Bank of Canada (2015). Inflation, expectations and monetary policy. Remarks by Agatha Cote.

Beechey, M. J., Johannsen, B. K., and Levin, A. T. (2011). Are long-run inflation expectations anchored more firmly in the Euro Area than in the United States? American Economic Journal: Macroeconomics, 3:104-129.

Christensen, J. and Gillan, J. (2012). Do Fed TIPS purchases affect market liquidity? FRBSF Economic Letter, 7. 
Demertzis, M. and Viegi, N. (2008). Inflation targets as focal points. International Journal of Central Banking, 4:55-87.

Demertzis, M. and Viegi, N. (2009). Inflation targeting: A framework for communication. The B.E. Journal of Macroeconomics, 9(1).

Dovern, J., Fritsche, U., and Slacalek, J. (2012). Disagreement among forecasters in G7 countries. Review of Economics and Statistics, 94(4):1081-1096.

Draghi, M. (2012). Speech at the global investment conference in London, 26 july 2012.

ECB (2006). Measures of inflation expectations in the Euro Area. Monthly Bulletin, July:5968.

ECB (2011). Inflation expectations in the Euro Area: A review of recent developments. Monthly Bulletin, February:73-86.

ECB (2012a). Assessing the anchoring of longer-term inflation expectations. Monthly Bulletin, July:65-78.

ECB (2012b). ECB announces expanded asset purchase programme. Press Release, 22 January 2015.

ECB (2014). The ECB's forward guidance. Monthly Bulletin, April:65-73.

Fazio, D. M., Tabak, B. M., and Cajueiro, D. O. (2015). Inflation targeting: Is IT to blame for banking system instability? Journal of Banking \& Finance, October(59):76 - 97.

Friedmann, M. (1961). The lag in effect of monetary policy. Journal of Political Economy, 69:447-466.

Galati, G., Poelhekke, S., and Zhou, C. (2011). Did the crisis affect inflation expectations? International Journal of Central Banking, 7:167-207.

Gürkaynak, R. S., Sack, B., and Swanson, E. (2005). The sensitivity of long-term interest rates to economic news: Evidence and implications for macroeconomics models. American Economic Review, 95:425-436.

Gürkaynak, R. S., Sack, B., and Wright, J. H. (2010a). The TIPS yield curve and inflation compensation. American Economic Journal: Macroeconomics, 2:70-92.

Gürkaynak, R. S., Swanson, E., and Levin, A. (2010b). Does inflation targeting anchor longrun inflation expectations? Evidence from the U.S., UK, and Sweden. Journal of the European Economic Association, 8:1208-1242.

Hördahl, P. (2008). The inflation (risk premium in the term structure of interest rates. BIS Quarterly Review.

Legerstee, R. and Franses, P. H. (2015). Does disagreement amongst forecasters have predictive value? Journal of Forecasting, July(4):290-302.

Loftus, E. F. and Palmer, J. C. (1974). Reconstruction of auto-mobile destruction: An example of the interaction between language and memory. Journal of Verbal Learning and Verbal Behavior, 13:585-589. 
Nautz, D. and Strohsal, T. (2015). Are US inflation expectations re-anchored? Economics Letters, 127:6-9.

Orphanides, A. and Williams, J. C. (2005). Inflation scares and forecast-based monetary policy. Review of Economic Dynamics, 8(2):498 - 527.

Paulhus, D. L. (2002). Socially desirable responding: The evolution of a construct. In Braun, H. I., Jackson, D. N., and Wiley, D. E., editors, The role of constructs in psychological and educational measurement, chapter 4, pages 49-69. Erlbaum, Mahwah, NJ.

Perron, P. (2006). Dealing with structural breaks. In Mills, T. and Patterson, K., editors, Palgrave Handbook of Econometrics, Vol. 1: Econometric Theory, chapter 4, pages 278-352. Palgrave, Basingstoke, UK.

Schmidt, S. and Nautz, D. (2012). Central bank communication and the perception of monetary policy by financial market experts. Journal of Money, Credit and Banking, 44(2-3):323340.

Smith, V. L. (1982). Microeconomics systems as an experimental science. American Economic Review, 72:923-955.

Strohsal, T. and Winkelmann, L. (2015). Assessing the anchoring of inflation expectations. Journal of International Money and Finance, 50:33-48.

van der Klaauw, W., Bruine de Bruin, W., Topa, G., Potter, S., and Bryan, M. (2008). Rethinking the measurement of household inflation expectations: preliminary findings. Federal Reserve Bank of New York, Staff Reports, 359. 


\section{A. Data: Sources and Definitions}

Table 4 provides more information on the employed data. Macroeconomic news variables obtained from the Bloomberg surveys are computed by comparing the realized values of the variables to the corresponding survey medians, see Section 3.4 .

\section{Table 4 Data}

\begin{tabular}{|c|c|c|}
\hline Abbreviation & Variable & Explanation \\
\hline GDP & $\begin{array}{l}\text { Gross Domestic Product } \\
\text { (news component) }\end{array}$ & $\begin{array}{l}\text { market value of all goods and services } \\
\text { produced in the euro area, source: } \\
\text { Bloomberg }\end{array}$ \\
\hline IP & $\begin{array}{l}\text { Industrial Production } \\
\text { (news component) }\end{array}$ & $\begin{array}{l}\text { volume of mining and producing in- } \\
\text { dustry as well as public supply of } \\
\text { electricity, gas and water, source: } \\
\text { Bloomberg }\end{array}$ \\
\hline UER & $\begin{array}{l}\text { Rate of Unemployment } \\
\text { (news component) }\end{array}$ & $\begin{array}{l}\text { average value of the entire euro area, } \\
\text { source: Bloomberg }\end{array}$ \\
\hline TB & $\begin{array}{l}\text { Trade Balance with Non- } \\
\text { EU (news component) }\end{array}$ & $\begin{array}{l}\text { difference between export and import, } \\
\text { source: Bloomberg }\end{array}$ \\
\hline CPI & $\begin{array}{l}\text { Harmonized Consumer } \\
\text { Price Index (news com- } \\
\text { ponent) }\end{array}$ & $\begin{array}{l}\text { yearly change of the price of a basket of } \\
\text { goods and services, consumed by the } \\
\text { average European consumer, source: } \\
\text { Bloomberg }\end{array}$ \\
\hline PPI & $\begin{array}{l}\text { Producer Price Index } \\
\text { (news component) }\end{array}$ & $\begin{array}{l}\text { change of the price of goods when } \\
\text { leaving their place of production, } \\
\text { source: Bloomberg }\end{array}$ \\
\hline GEP & $\begin{array}{l}\text { Government Expenditure } \\
\text { (news component) }\end{array}$ & $\begin{array}{l}\text { part of the GDP that is spent by the } \\
\text { government, source: Bloomberg }\end{array}$ \\
\hline Euribor & $\begin{array}{l}\text { Euro Interbank Offered } \\
\text { Rate }\end{array}$ & $\begin{array}{l}\text { change of the three-month Euribor at } \\
\text { monetary policy announcement days, } \\
\text { source: Bloomberg }\end{array}$ \\
\hline BEIR & $\begin{array}{l}\text { 5-Year Forward BEI Rate } \\
5 \text { Years Ahead }\end{array}$ & $\begin{array}{l}\text { market-based measure of inflation ex- } \\
\text { pectations, source: Jan } 2006 \text { to Feb } \\
\text { 2012, ECB, Mar } 2012 \text { to Jan 2015, } \\
\text { Bloomberg }\end{array}$ \\
\hline spread & corporate bond spread & $\begin{array}{l}\text { the spread between an AAA-rated cor- } \\
\text { porate bond yield and the the yield of } \\
\text { a nominal government bond, source: } \\
\text { Datastream, ECB }\end{array}$ \\
\hline VSTOXX & $\begin{array}{l}\text { EURO STOXX } 50 \text { Volatil- } \\
\text { ity index }\end{array}$ & $\begin{array}{l}\text { a measure of the implied volatility of } \\
\text { the EURO STOXX } 50 \text { index referring to } \\
\text { the next } 30 \text { days, source: Bloomberg }\end{array}$ \\
\hline
\end{tabular}


Figure 2 Macroeconomic News in the Euro Area

GDP
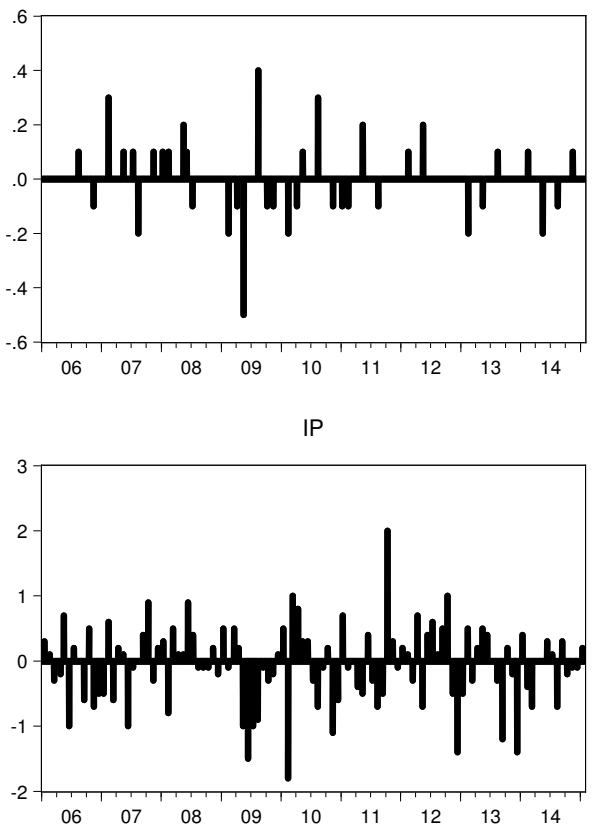

ER

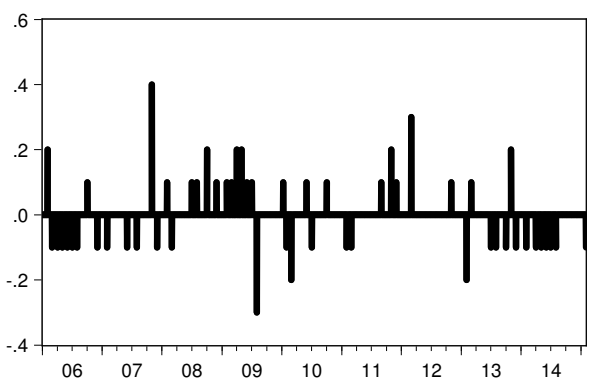

TB

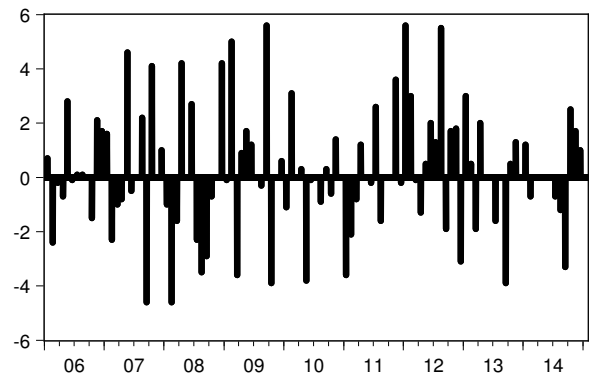

$\mathrm{CPI}$
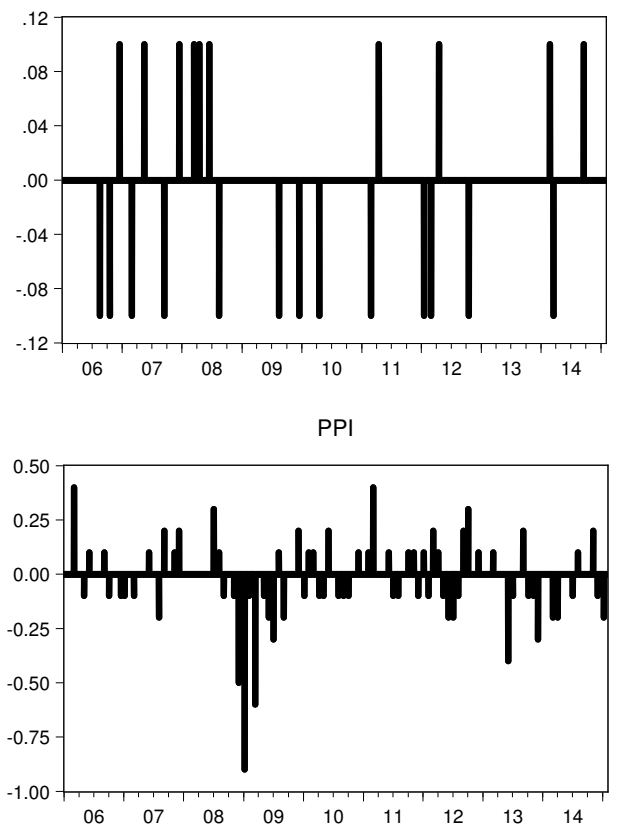

GEP

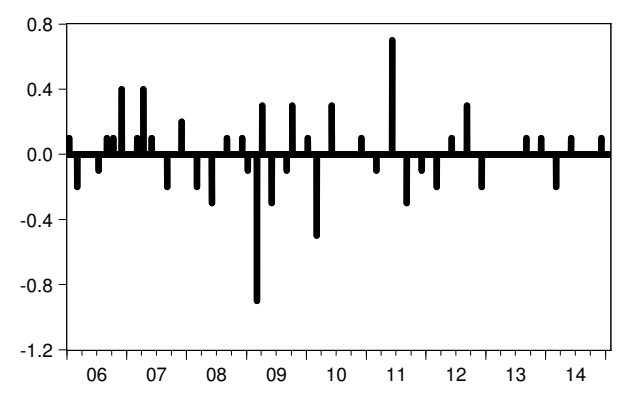

Euribor

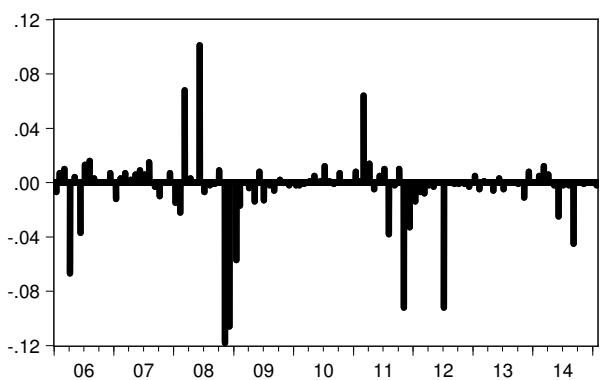

Notes: The figure shows the realizations of the news variables, cf. Table 4 


\section{B. Liquidity Adjustment of BEI Rates}

Table 5 presents the results of the liquidity adjustment regression (1)

$$
B E I R=\gamma+\delta_{1} \operatorname{spread}_{t}+\delta_{2} \operatorname{VIX}_{t}+f_{t}
$$

described in section 3.2. The estimated coefficients of the liquidity measures for the 5-year forward rate 5 years ahead (BEIR) are both highly significant and plausibly signed.

Table 5 The Liquidity Adjustment Regression of the BEI Rate

\begin{tabular}{|l|ccc|c|c|}
\hline & constant & spread & VIX & joint test & $R^{2}$ \\
\hline coefficient & 2.091 & 0.232 & 0.003 & 60.132 & 0.048 \\
p-value & $(0.00)$ & $(0.00)$ & $(0.00)$ & $(0.00)$ & \\
\hline Notes:
\end{tabular}
eroskedasticity and autocorrelation consistent standard errors. For more information on the data, see Appendix A

\section{Multiple Endogenous Structural Break Point Tests}

The break point tests are based on the methodology of Bai (1997) and Bai and Perron (1998). The sequential Bai (1997) test starts by searching for the most likely break in the sample. If this break is significant, the procedure is repeated for both new subsamples. The testing procedure stops when the null of no additional break cannot be rejected for the first time. The Bai and Perron (1998) test combines the sequential procedure of Bai (1997) with a global break point search according to

$$
\sum_{i=1}^{l+1} \sum_{t=T_{i-1}+1}^{T_{i}}\left(\Delta f_{t}-\hat{\alpha}-\hat{\beta}_{i} X_{t}\right)^{2},
$$

which is conducted under the alternative hypothesis. The test statistic is given by

$$
F\left(T_{1}, \ldots, T_{t} ; q\right)=\frac{1}{T}\left(\frac{T-(l+1) q-p}{l}\right) \hat{\beta}^{\prime} R^{\prime}\left(R \hat{V}(\hat{\beta}) R^{\prime}\right)^{-1} R \hat{\beta}
$$


with $T_{0}=0$ and $T_{l+1}=T . V(\hat{\beta})$ is a heteroskedasticity and autocorrelation consistent estimate of the covariance matrix of breaking regression coefficients. $R \hat{\beta}=\left(\hat{\beta}_{1}{ }^{\prime}-\hat{\beta}_{2}{ }^{\prime}-\ldots-\right.$ $\left.\hat{\beta}_{l}{ }^{\prime}-\hat{\beta}_{l+1}{ }^{\prime}\right)$ and $R$ is defined accordingly. $q$ and $p$ stand for the numbers of breaking and nonbreaking coefficients, respectively. Bai and Perron (2003a) propose an efficient algorithm to reduce the computational burden of the global search. Simulated critical values are provided by Bai and Perron (2003b). For a more comprehensive discussion of multiple break tests, see Perron (2006). 


\section{SFB 649 Discussion Paper Series 2015}

For a complete list of Discussion Papers published by the SFB 649, please visit http://sfb649.wiwi.hu-berlin.de.

001 "Pricing Kernel Modeling" by Denis Belomestny, Shujie Ma and Wolfgang Karl Härdle, January 2015.

002 "Estimating the Value of Urban Green Space: A hedonic Pricing Analysis of the Housing Market in Cologne, Germany" by Jens Kolbe and Henry Wüstemann, January 2015.

003 "Identifying Berlin's land value map using Adaptive Weights Smoothing" by Jens Kolbe, Rainer Schulz, Martin Wersing and Axel Werwatz, January 2015.

004 "Efficiency of Wind Power Production and its Determinants" by Simone Pieralli, Matthias Ritter and Martin Odening, January 2015.

005 "Distillation of News Flow into Analysis of Stock Reactions" by Junni L. Zhang, Wolfgang K. Härdle, Cathy Y. Chen and Elisabeth Bommes, January 2015.

006 "Cognitive Bubbles" by Ciril Bosch-Rosay, Thomas Meissnerz and Antoni Bosch-Domènech, February 2015.

007 "Stochastic Population Analysis: A Functional Data Approach" by Lei Fang and Wolfgang K. Härdle, February 2015.

008 "Nonparametric change-point analysis of volatility" by Markus Bibinger, Moritz Jirak and Mathias Vetter, February 2015.

009 "From Galloping Inflation to Price Stability in Steps: Israel 1985-2013" by Rafi Melnick and till Strohsal, February 2015.

010 "Estimation of NAIRU with Inflation Expectation Data" by Wei Cui, Wolfgang K. Härdle and Weining Wang, February 2015.

011 "Competitors In Merger Control: Shall They Be Merely Heard Or Also Listened To?" by Thomas Giebe and Miyu Lee, February 2015.

012 "The Impact of Credit Default Swap Trading on Loan Syndication" by Daniel Streitz, March 2015.

013 "Pitfalls and Perils of Financial Innovation: The Use of CDS by Corporate Bond Funds" by Tim Adam and Andre Guettler, March 2015.

014 "Generalized Exogenous Processes in DSGE: A Bayesian Approach" by Alexander Meyer-Gohde and Daniel Neuhoff, March 2015.

015 "Structural Vector Autoregressions with Heteroskedasticy" by Helmut Lütkepohl and Aleksei Netšunajev, March 2015.

016 "Testing Missing at Random using Instrumental Variables" by Christoph Breunig, March 2015.

017 "Loss Potential and Disclosures Related to Credit Derivatives - A CrossCountry Comparison of Corporate Bond Funds under U.S. and German Regulation" by Dominika Paula Gałkiewicz, March 2015.

018 "Manager Characteristics and Credit Derivative Use by U.S. Corporate Bond Funds" by Dominika Paula Gałkiewicz, March 2015.

019 "Measuring Connectedness of Euro Area Sovereign Risk" by Rebekka Gätjen Melanie Schienle, April 2015.

020 "Is There an Asymmetric Impact of Housing on Output?" by Tsung-Hsien Michael Lee and Wenjuan Chen, April 2015.

021 "Characterizing the Financial Cycle: Evidence from a Frequency Domain Analysis" by Till Strohsal, Christian R. Proaño and Jürgen Wolters, April 2015.

\section{SFB 649, Spandauer Straße 1, D-10178 Berlin http://sfb649.wiwi.hu-berlin.de}




\section{SFB 649 Discussion Paper Series 2015}

For a complete list of Discussion Papers published by the SFB 649, please visit http://sfb649.wiwi.hu-berlin.de.

022 "Risk Related Brain Regions Detected with 3D Image FPCA" by Ying Chen, Wolfgang K. Härdle, He Qiang and Piotr Majer, April 2015.

023 "An Adaptive Approach to Forecasting Three Key Macroeconomic Variables for Transitional China" by Linlin Niu, Xiu Xu and Ying Chen, April 2015.

024 "How Do Financial Cycles Interact? Evidence from the US and the UK" by Till Strohsal, Christian R. Proaño, Jürgen Wolters, April 2015.

025 "Employment Polarization and Immigrant Employment Opportunities" by Hanna Wielandt, April 2015.

026 "Forecasting volatility of wind power production" by Zhiwei Shen and Matthias Ritter, May 2015.

027 "The Information Content of Monetary Statistics for the Great Recession: Evidence from Germany" by Wenjuan Chen and Dieter Nautz, May 2015.

028 "The Time-Varying Degree of Inflation Expectations Anchoring" by Till Strohsal, Rafi Melnick and Dieter Nautz, May 2015.

029 "Change point and trend analyses of annual expectile curves of tropical storms" by P.Burdejova, W.K.Härdle, P.Kokoszka and Q.Xiong, May 2015.

030 "Testing for Identification in SVAR-GARCH Models" by Helmut Luetkepohl and George Milunovich, June 2015.

031 "Simultaneous likelihood-based bootstrap confidence sets for a large number of models" by Mayya Zhilova, June 2015.

032 "Government Bond Liquidity and Sovereign-Bank Interlinkages" by Sören Radde, Cristina Checherita-Westphal and Wei Cui, July 2015.

033 "Not Working at Work: Loafing, Unemployment and Labor Productivity" by Michael C. Burda, Katie Genadek and Daniel S. Hamermesh, July 2015.

034 "Factorisable Sparse Tail Event Curves" by Shih-Kang Chao, Wolfgang K. Härdle and Ming Yuan, July 2015.

035 "Price discovery in the markets for credit risk: A Markov switching approach" by Thomas Dimpfl and Franziska J. Peter, July 2015.

036 "Crowdfunding, demand uncertainty, and moral hazard - a mechanism design approach" by Roland Strausz, July 2015.

037 ""Buy-It-Now" or "Sell-It-Now" auctions : Effects of changing bargaining power in sequential trading mechanism" by Tim Grebe, Radosveta Ivanova-Stenzel and Sabine Kröger, August 2015.

038 "Conditional Systemic Risk with Penalized Copula" by Ostap Okhrin, Alexander Ristig, Jeffrey Sheen and Stefan Trück, August 2015.

039 "Dynamics of Real Per Capita GDP" by Daniel Neuhoff, August 2015.

040 "The Role of Shadow Banking in the Monetary Transmission Mechanism and the Business Cycle" by Falk Mazelis, August 2015.

041 "Forecasting the oil price using house prices" by Rainer Schulz and Martin Wersing, August 2015.

042 "Copula-Based Factor Model for Credit Risk Analysis" by Meng-Jou Lu, Cathy Yi-Hsuan Chen and Karl Wolfgang Härdle, August 2015.

043 "On the Long-run Neutrality of Demand Shocks" by Wenjuan Chen and Aleksei Netsunajev, August 2015.

\section{SFB 649, Spandauer Straße 1, D-10178 Berlin http://sfb649.wiwi.hu-berlin.de}




\section{SFB 649 Discussion Paper Series 2015}

For a complete list of Discussion Papers published by the SFB 649, please visit http://sfb649.wiwi.hu-berlin.de.

044 "The (De-)Anchoring of Inflation Expectations: New Evidence from the Euro Area" by Laura Pagenhardt, Dieter Nautz and Till Strohsal, September 2015.

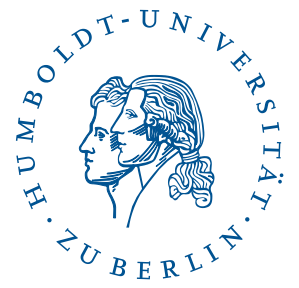

